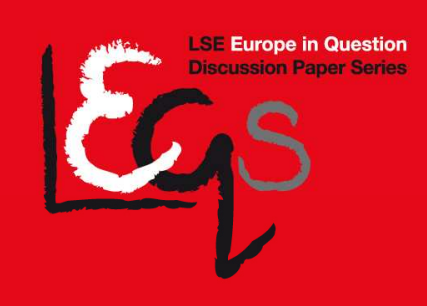

LSE 'Europe in Question’ Discussion Paper Series

\title{
Left, Right and Beyond: the Pragmatics of \\ Political Mapping
}

Jonathan White






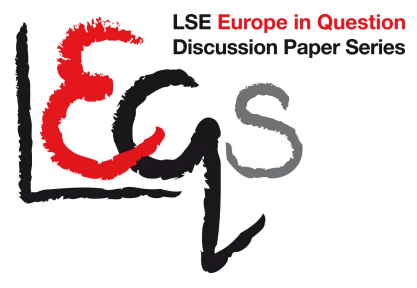

\section{Editorial Board}

Dr. Joan Costa-i-Font

Dr. Vassilis Monastiriotis

Dr. Jonathan White

Ms. Katjana Gattermann

All views expressed in this paper are those of the author and do not necessarily represent the views of the editors or the LSE.

(C) Jonathan White 


\title{
Left, Right and Beyond: the
}

\section{Pragmatics of Political Mapping}

\author{
Jonathan White*
}

\begin{abstract}
This paper examines the political categories of 'Left' and 'Right', in particular as they are evoked and instrumentalised by political actors in the democratic process. Drawing on some of the insights of positioning theory, it shows how 'Left' and 'Right' are discursive resources deployed, contested and resisted in political exchange. The paper looks in depth at some of the political uses to which Left-Right talk may be put, discussing in particular acts of partisan profiling, of legitimisation and subversion, and the evocation or rejection of political continuity. The paper argues that while these usages can be seen as strategic moves pursued for political advantage, they have a larger significance insofar as they indicate one of the ways the democratically important imagery of Left and Right may remain active in European politics.
\end{abstract}

\footnotetext{
* London School of Economics

Lecturer in European Politics, European Institute, Houghton St, London WC2A 2AE, UK Email: j.p.white@lse.ac.uk
} 


\section{Table of Contents}

Abstract

Introduction

Left, Right and the Practices of Positioning

Left-Right Talk: Dimensions of Partisan Usage

1. Partisan Profiling

2. Legitimising and Subverting

3. Evoking Continuity and Rupture

Substitutions

Conclusion

References

\section{Acknowledgements}

First comments on this paper were gratefully received from the participants of the 'CategoryMaking and Public Policy' workshop at the 2010 ECPR Joint Sessions in Münster, Germany. Special thanks also to Marco Dani and Katjana Gattermann. 


\section{Left, Right and Beyond: the}

\section{Pragmatics of Political Mapping}

'There's nothing right-wing about the BNP.'

Daniel Hannan MEP (Conservative), The Telegraph, 22 ${ }^{\text {nd }}$ February 2009.

\section{Introduction}

It is often when there is the suspicion something is in decline that scholars make it the topic of serious reflection. Things whose vitality or appeal seemed self-evident come to be regarded as contingent things to be accounted for and perhaps defended or mourned. What has been true in recent years of a wide range of political phenomena, from the nation-state to active citizenship and civil society, seems to have some pertinence also for the political categories of Left and Right. While still typically invoked for analytical purposes rather than as a distinctive object of study, Left and Right have been given detailed consideration in several works of the last two decades. Almost all contributions have felt it necessary to discuss, though they have often disputed, the possibility that these categories are on the wane. ${ }^{1}$

The question of what lies in store for Left and Right points naturally to the more basic question of what exactly these terms are about, and here two major approaches can be discerned. One approach - broadly political-philosophical - regards them as expressing quite stable traditions of political ideas. ${ }^{2}$ Theorists have laid out what they see as the enduring commitments of Left and Right, treating them either as largely self-standing orientations or as dyads which derive their meaning from clashes of view on specific concerns. Some such accounts treat the two traditions as

${ }^{1}$ See e.g. Bobbio 1996, Lukes 2003, Noel and Therien 2008, Gauchet 1994, Giddens 1994, Mouffe 2005.

2 Bobbio 1994, Lukes 2003, Kymlicka 2002. 


\section{Left, Right and Beyond}

rooted in divergent core values (e.g. equality and liberty, progress and stability); others regard them as rooted in differing interpretations and weightings of the same values and concepts and differences concerning how they are best served. Common to these readings is the view that whatever variation in the meaning of Left and Right may exist across time and space is less important than the core set of meanings which stays largely the same. A second approach - broadly social-scientific - instead takes a strictly empiricist view on the question of continuity and variation, treating Left and Right as flexible categories which mean roughly whatever a certain set of key actors or a statistically significant sample of a given population says that they mean. Insofar as long-standing patterns are identified, this approach is compatible with the first, although often these studies insist on the openness of such beliefs to cultural difference and temporal change. ${ }^{3}$

Both these approaches to Left and Right aim to identify the semantic content of the terms, i.e. the traditions and conflicts they symbolise. Their methods and conclusions may differ, but the problématique is much the same. No longer pegged to the East-West geopolitical axis of twentieth-century politics, what meaning does the dualism retain? Both approaches are able to say interesting things about the continuing or diminishing vitality of Left and Right as markers for political traditions, be they universal or localised, and about the democratic implications of different readings of the situation.

In this paper I do not wish to argue against the validity of these approaches and the questions they raise, but instead to indicate how an understanding of Left and Right addressed exclusively to the ideas they do or do not index would be incomplete. For there is another dimension to their existence as political categories which relates to the way they are invoked and put to work in political discourse. 'Left' and 'Right' are discursive resources drawn upon, contested and resisted in political exchange themselves the site of conflict as much as an exogenous device for its representation. When a Conservative MEP seeks to explain why the British National Party has, contrary to popular belief, little in common with the 'mainstream Right', or when

\footnotetext{
3 E.g. Fuchs and Klingemann 1990.
} 
certain partisans invoke for themselves the name of 'The Left Party', or indeed when others deny the enduring relevance of these categories, their actions are properly seen not as a detached exercise in description but one with performative intent and / or political consequence. To be sure, the possibility of engaging in such actions is largely predicated on Left and Right being seen to enjoy some level of stable semantic content (else they would presumably lack prestige), but once this is true they take on a second life as discursive resources with which actors can play. Worthy of attention therefore are the purposes which inform the adoption of 'Left' and 'Right' (and their correlate the 'Centre') in day-to-day politics and the effects which are thereby achieved.

This paper outlines several dimensions of the categories' deployment in political discourse, drawing in part on the insights of positioning theory. ${ }^{4}$ This focus on the political usage of the Left-Right vocabulary finds at least one justification in the fact that it is in this form that contemporary citizens are most likely to be exposed to the terms. While students of politics may encounter and deploy them as fairly impartial analytical terms, their everyday appearance is likely to be more loaded, as political actors apply them for political gain and as these moves in turn are amplified in the media. These partisan usages will also subsequently come to influence the wider set of meanings the terms make available and the appeal which adopting them may hold: one way or another, Left and Right are likely to bear the traces of partisan usage.

Perhaps the key significance of the uses to which Left and Right can be put lies however in the implications for the very durability of this political vocabulary. It is sometimes suggested that the Left-Right scheme plays a crucial democratic function, enabling the recognition and legitimation of political discord. ${ }^{5}$ Some have suggested its absence or subordination to alternative political registers, as perhaps in the European Union, marks the immaturity of a political system. If this is so - here is not the place to put it in question - then it seems plausible to assume that an

${ }^{4}$ See the work of Rom Harré and his co-authors, e.g. Harré \& van Langenhove 1999.

${ }^{5}$ Dyrberg 2005. 


\section{Left, Right and Beyond}

important guide to whether the Left-Right idiom can be expected to survive and extend to new political arenas is the degree to which political actors have local reason to employ it. By examining the tactical usage or repudiation of the vocabulary, one can thus probe whether harmony is likely between a certain kind of democratic ideal and the more pragmatic concerns of political actors. Further, one can consider whether the uses to which Left and Right may be put are conducive to the categories having wider public resonance, or conversely whether they may contribute to the categories' broader eclipse.

\section{Left, Right and the Practices of Positioning}

Familiar readings of Left and Right, be they in scholarship, political discourse or journalism, tend to see them as terms providing a representational device for thinking about clusters of political views and their possible relations. As already noted, they may be seen as largely atemporal, with core meanings attached to each, meanings more fundamental than (existing, as it were, on a different plane from) whatever political views happen to be articulated in a given time and place. Alternatively they may be seen rather as a snapshot of the ideational configuration of a particular setting, with each term defined locally according to the views found there in circulation. ${ }^{6}$ Additionally, they may be thought of as forming two poles on a continuum or 'spectrum', or they may be thought of dualistically as discrete, counter-posed entities. In all such accounts, the Left-Right vocabulary is treated principally as something which communicates politics and political conflict rather than itself being the site of these activities. That is to say, attention is directed beyond the language itself to that which the language enables us to understand. One sees this idea in some of the metaphors used for Left and Right: it has been referred to for instance as the 'core currency of political exchange'. ${ }^{7}$ In normal times,

\footnotetext{
${ }^{6}$ The referent of Left and Right may thus be seen variously as an immutable political space which exists prior to the political actors who occupy it, or as the spread of views articulated by partisans in a particular time and place, or as the wider set of views current in a given society (perhaps understood as a causal factor shaping the views articulated at the partisan-elite level). ${ }^{7}$ McDonald, Mendes and Kim 2007.
} 
the role of a currency is to measure, to offer a means of calibration for values external to itself. Likewise the comparison with a language, 'Esperanto': languages are typically understood as media rather than objects with a life of their own. ${ }^{8}$ Another metaphor one hears is that of the map: again, in the usual understanding, a map's role is to communicate to us information about something which lies beyond the map. While currencies, languages and maps can be the subject of contestation, this is not what we associate with them in the normal run of things.

For the detached observer who seeks to analyse patterns of political behaviour, just as for the engaged citizen who needs a workable representation of the political options available, this conception of Left and Right will often be valid. But two caveats are necessary, ones which point us to an alternative approach. First, representations of the political world can never be definitive. The descriptions which can be provided using the Left-Right framework, just as those which competing schemes can offer, are never beyond contestation. The reason is that one cannot expect a perfect symmetry of understanding across all actors in the political field. Even assuming the most dispassionate motivations, people are likely to differ on at least one of the following points: 1) they may disagree on what the organising terms 'Left' and 'Right' mean. Given the Left-Right distinction is substantively ambiguous, it is debatable what metric it is supposed to evoke - whether it refers to conceptions of equality, for example, or the relation between equality and other values (e.g. liberty), or the level of commitment to rectifying inequality, or to conceptions of human nature (its improvability or resistance to improvement), or to conceptions and attitudes towards historical change (e.g. stability vs progress). Empirical research seems to confirm this diversity of interpretations, albeit diversity which is not unbounded. ${ }^{9}$ 2) Even if people have a common understanding of the structure of political conflict, they may disagree on where particular political groupings are to be located in it. They may disagree, for instance, on who is 'Right' and who is 'Left', with the scope for disagreement all the greater if these terms are understood to be poles on a continuum (is there a Centre, and if so where does it

\footnotetext{
${ }^{8}$ Laponce 1981, p.56.

${ }^{9}$ Fuchs and Klingemann 1990.
} 


\section{Left, Right and Beyond}

lie?). 3) More radically, there may be disagreement even on the fundamental question of whether single-axis schemes such as Left and Right constitute a valid way of expressing the distribution of political views. Some will object to what they see as the simplification and distortion of debate this entails, while others may be uncomfortable with the image of conflict rather than consensus it may imply.

Asymmetry of understanding across the citizen body seems predictable. The political world is ineradicably complex, and no representation of it is likely to overcome this - perhaps certainly not one reliant on the simple yet ambiguous imagery of Left and Right. There is no 'political grammar' by which to regulate definitively the correct and incorrect application of the Left-Right scheme. ${ }^{10}$ Some readings may be easily identified as idiosyncratic, but no single reading can be pinpointed as incontestable, and it may be that several appear of which none can easily be dismissed. If this is so, and 'neutral' readings are known to be unreachable, it opens the possibility of Left and Right being the subject of play. Differing applications of the terminology are likely to come up against one another, and may become the site of contestation.

This connects to the second major caveat, which is that not only are different readings of the political world possible but that different readings carry different political implications, and individuals who have established political goals may therefore be motivated to pursue some readings over others. ${ }^{11}$ The stakes are high when it comes to political mapping, as different representations of the political world may have serious consequences for the profile and appeal of particular viewpoints: as we shall examine further, they imply different things about which political actors are important and which minor, about where the important lines of political difference lie, and about the moral status of a given political perspective. For a party to be described as 'far Left', for instance, is arguably for it to be described not just as adopting certain political commitments but also as being 'extreme', in the sense either of adopting radical (i.e. unusual, non-mainstream) political views or,

\footnotetext{
${ }^{10}$ Cf. Eatwell 1989, p.32.

${ }^{11}$ Bobbio 1996 is generally quiet on this matter, though see p.37, p.52.
} 
perhaps as a function of this, in the sense of being morally suspect. The party thus described, though it may welcome some such connotations, may wish to dispute others, either by contesting its placement on the spectrum or by contesting the spectrum's meaning and / or relevance. From this point derives the motivation for partisans to seek to promote their favoured representation of the political world in a competitive clash with alternatives. Right and Left, in other words, become political resources for reflexive political actors, affording opportunities to those who have control over them and risks to those who do not. In Bourdieu's terms, they are a potential source of symbolic capital. ${ }^{12}$ One has good reason therefore to study how actors appropriate, resist, or indeed ignore, the Left-Right terminology.

These practices of self- and other-categorisation using the vocabulary of Left and Right have notable resonance with the practices described by theorists of positioning. ${ }^{13}$ It is an approach which places particular emphasis on the situationspecific and contested usage of terms. Rather than seeing speakers as fixed occupants of largely static roles or identities, this approach sees them as engaged in an ongoing discursive process which involves the local assignation and acceptance or refusal of 'positions'. ${ }^{14}$ Positions are defined relationally, like Left and Right, are constructed in the individual speech situation, and may therefore be relatively transient. This does not contradict the idea of higher-order meanings which can be brought in to regulate and criticise usage - indeed, 'meta-positionings' of this kind are what enable contestation. In the case of Left and Right, one can affirm that they have certain standardised or 'sedimented' meanings which place limits on the positioning moves which actors can engage in, while noting that their application retains plenty of scope for choice and decision. ${ }^{15}$ Conflict may arise when an initial,

\footnotetext{
12 Bourdieu 1991.

${ }^{13}$ Harré \& van Langenhove 1999, Harre \& Moghaddam 2003. Our focus in this paper is on the agential rather than the structural, i.e. on how speakers use language rather than how 'language uses speakers'; it is worth emphasising though that individual actions are interesting partly because it is precisely these which set the wider discursive context in which other individual actions are taken. Note also that the meaning of 'positioning' is distinct from standard uses in electoral analysis, which refer to the observer's identification of adversarial issues and their placement of parties on a one-dimensional scale accordingly.

${ }^{14}$ Harré et al 2009 p.10.

15 On the conventional meanings of Right and Left in contemporary societies, see Fuchs and Klingemann, 1990. Persistent challenges and variations of usage will have consequences for
} 


\section{Left, Right and Beyond}

'first-order' act of positioning, rather than being tacitly accepted, comes to be contested in a 'second-order' move: when, for instance, the invocation of 'Left' or 'Right' is explicitly rejected by another party to the discussion. ${ }^{16}$ As suggested, this contestation of positions may derive from the asymmetrical understanding of different actors, or because of the different moral content of different positions and how this may determine the meanings which actions carry. While positioning theory was developed initially for the micro-conversational setting, it has been usefully extended to larger scales for the study national and international politics, and it has relevance for the actions we shall discuss. ${ }^{17}$

Positioning in the context of day-to-day politics has a distinctive characteristic, which is that it takes place before a potentially large public. When partisans invoke categories to position themselves and others, they do so in a context where their chief audience is not necessarily their interlocutor but the anticipated one of citizens in general. In representative democracy, representatives are one of the prime movers in the positioning game. Sometimes representatives may make explicit efforts to position large numbers of citizens (e.g. by evoking the moral outrage of a 'silent majority'), a kind of positioning which is largely unilateral since only at certain electoral or revolutionary moments can those who are addressed answer back in an act of second-order positioning. More often the addressee will be other representatives - e.g. members of opposing parties. But even then, when the majority of the population is an ostensibly passive audience, the role of the presumed listener is a critical one in giving sense and urgency to acts of positioning.

Left and Right, we may provisionally conclude, are immanent to political conflict rather than an exogenous framework by which to represent it. Yet precisely because the terms are widely believed to be separate from the site of conflict, to be fairly neutral terms of analysis, political actors can use them to achieve desired outcomes.

these larger sedimented meanings (and indeed can undermine them if usage becomes arbitrary): in the long term the semantic content of the terms does not 'transcend' the usage which is made of them, a point we shall return to in the Conclusion.

16 See distinction between first- and second-order positioning (Harré and van Langenhove 1992, p.396).

17 Harré and Lee 2008. 
Their status as political resources derives in significant part from their ostensible function as mere descriptors.

\section{Left-Right Talk: Dimensions of Partisan Usage}

Let us move on to consider more closely the kinds of political use to which the categories 'Left' and 'Right' may be put. The following discussion is distinctly qualitative and interpretative in approach, based on a logic of purposeful selection. It does not examine the frequency with which Left and Right are invoked in a given corpus of text, nor the most common contexts in which such usage arises. It does not, for instance, systematically examine whether some moments in the political cycle are particularly prone to producing such talk, what the significance of different kinds of political system may be, or of a party's role in government or opposition. ${ }^{18}$ Rather it looks at the effects the terms can be used to achieve when called upon. It analyses several rich instances of the usage of Left-Right in contemporary European politics, chosen for their suggestiveness and for their association with diverse ideological traditions and electoral systems, using them to bring out some of the important features of political usage. ${ }^{19}$ While the collection is no doubt incomplete, it nonetheless well serves the larger goal of enabling a better appreciation of that distinctive aspect of Left and Right which is their dynamic deployment in political exchange.

\section{Partisan Profiling}

Perhaps the most familiar use of these categories is the effort to indicate how different party groupings relate to one another and thereby to map the political field.

\footnotetext{
${ }^{18}$ For some discussion of this see Laponce 1981 and Gauchet 1994.

${ }^{19}$ Note that the following three sub-sections are intended progressively to unfold some of the complexity of partisan usage: they should not be understood as discrete categories - the first idea is an encompassing one, within which the second and third may be nested - and the empirical material cited generally has relevance to more than one.
} 


\section{Left, Right and Beyond}

Left and Right can be used to identify friends and adversaries in a way which is easily grasped and with a certain dramatic power. Analytically one may distinguish between acts of self-positioning, which invoke Left or Right to characterise the speaker's own party grouping, and acts of other-positioning, which characterise the opponent. We shall examine an instance of the former in a later section when considering the emergence of Germany's Left Party (Linkspartei). It is important to remember however that all acts of positioning are relational, and so to engage in the one kind of positioning is simultaneously to engage in the other. ${ }^{20}$

An important matter in partisan profiling is the degree of proximity with which groups are positioned to each other. Left and Right can be used to position opponents as similar or identical to a generally disliked third party, intentionally overlooking the differences which may exist between them so as to discredit one by association with another: consider the efforts made to discredit social democrats during the Cold War by associating them with Soviet communism. ${ }^{21}$ Positing an alliance between one's adversaries allows a powerful frontier to be drawn between 'us' and 'them'. Precisely because the Left-Right spectrum is nebulous in its meaning and calibration, the validity of these comparisons is not always easily rejected, although the objects of a positioning move can of course seek to contest the positioning.

In the contemporary period, an interesting example is provided by the British Conservative MEP and journalist Daniel Hannan, in a newspaper article concerning how the British National Party (BNP) relates to other parties. Although a presence in British politics for some time, the BNP recently came to prominence due to victories in local council by-elections (notably Swanley in Kent in mid-February 2009, shortly before Hannan's article) as well as gains in the 2009 European Parliamentary elections. This challenge to the established structure of British politics - albeit a modest one - presents a novel situation to which other political actors may feel

\footnotetext{
${ }^{20}$ Harré and van Langenhove 1992, p.398.

${ }^{21}$ Cf. 'horse-shoe spectrums' (cf. Eatwell 1989 p.44) - spectrums in which the poles of Left and Right are bent round so as to lie next to each other, implying that communism and fascism are similar.
} 
compelled to respond, and indeed an opportunity for them to re-map the political landscape as they would like it to be appraised. Hannan's article, in the conservative Telegraph newspaper, goes under the heading 'There's nothing right-wing about the $\mathrm{BNP}^{\prime}{ }^{22}$ It sets up the argument that the BNP receives far more publicity than is warranted by the relatively low threat it poses to British society and politics. Having considered various possible reasons for why this should be so, the article reaches its climax as follows:

\begin{abstract}
'Above all, though, the BNP is used as an indirect weapon against the mainstream Right. You will have noticed that the party is almost never mentioned without the soubriquet "far Right". The BNP doesn't call itself Right-wing, of course. It favours nationalisation, higher taxes, protectionism and (though it keeps quiet about this) republicanism. It markets itself as "the Labour Party your parents voted for". Its manifesto calls for "the selective exclusion of foreign-made goods from British markets and the reduction of foreign imports," and promises to "restore our economy and land to British ownership" and "to give workers a stake in the success and prosperity of the enterprises whose profits their labour creates by encouraging worker shareholder and co-operative schemes". As Hayek wrote in 1944 in his brilliant chapter on "the socialist roots of Nazism", the dispute between fascists and socialists is a dispute between brothers. Labour and the BNP are, in a sense, competing for the same sort of voter: one who believes in the power of the state. The one kind of voter whom both fascists and socialists regard as beyond persuasion is the small-government Tory. The real purpose of banging on about the "far-Right BNP" is to damage, by association, the Conservatives. If hurting the Tories means giving the BNP enough free publicity to keep it alive, it's a price some Lefties seem happy to pay.'
\end{abstract}

The first thing one may notice here is the prominence given to the categories Left and Right: their significance as resources seems well recognised, since the piece is centrally concerned with protecting the reputation of the 'mainstream Right' from malign association, and with identifying the proper configuration of relations

22 The Telegraph, 22 ${ }^{\text {nd }}$ February 2009. 


\section{Left, Right and Beyond}

between its opponents. The text implicitly acknowledges that the Conservatives are indeed a party of the Right - an alternative distancing tactic would have been to deny this, perhaps re-positioning at the Centre or abandoning such categories altogether - and that the moral content of the category must be preserved unblemished. Coupled with this of course is the intent to conjure those agents of the Left who are to blame for this habit of association. These agents are positioned as frivolous and irresponsible ('Lefties' evidently being diminutive) and as lacking in morals (for they play this dangerous game in awareness that there is a price to be paid). Meanwhile the BNP, though its association with the Right is denied, is nonetheless implied to be a party which can be understood in Left-Right terms: there is no suggestion that it escapes such classification.

Notice in particular how the meaning of the Left-Right divide is defined. At stake is said to be the power of the State - not, for instance, the desire to seek the rectification of inequality. Whereas many - including a large number of those who self-identify with the Left - might see the question of the State as one of means rather than $e n d s,{ }^{23}$ and might be inclined to see statism as an orientation orthogonal to Left and Right, Hannan presents it as the crux of the debate. In so doing he draws on a line of reasoning often associated with thinkers of the Right: Hayek is the chosen source, though Karl Popper would have been a plausible alternative. ${ }^{24}$ That Left and Right are meaningful is the premise of the argument - behind them lie established ideological traditions (fascism, socialism and conservatism) which, it is suggested, continue to find expression in contemporary party politics. Yet the core of the LeftRight opposition is said to be how much government is desired. It is by evoking the political divide along this dimension that Hannan is able to re-position Labour and

${ }^{23}$ Consider for instance a text we shall return to by former British Labour Party leader and Prime Minister Gordon Brown (Brown 2010): while Left-Right disagreement over the role of the State is acknowledged, the real difference between the two is said to be the underlying one of values and principles (p.6), with the Left valuing fairness, equality, cooperation - 'values that the Right, quite simply, does not share. The Right has never been committed to equality, except in the most limited and formal of senses. They see equality and liberty as inherently in tension, and in this claimed trade-off prioritise liberty' (pp.29-30).

${ }^{24}$ Note that in the Hayek piece cited, the core of the link between socialism and fascism (or 'socialism of the Left and Right') is their organised collectivism (as opposed to individualism), and it is to liberalism rather than conservatism that they are opposed. Rather than merely replicating an established philosophical position, Hannan is thus reinterpreting it from a contemporary perspective and with contemporary purposes in mind. 
the BNP as in fact far closer to each other than either is to the Conservative Right, and to present them at all plausibly as 'brothers'. Thus Left and Right are not merely acknowledged in a defensive move but deployed offensively to redescribe the political scene as the speaker prefers.

As a rule, one might expect political actors to favour those representational schemes which allow their own grouping to occupy a distinctive location in political space while downplaying the differences amongst their opponents. In line with social identity theory, which posits that persons seek not just a positive sense of selfhood but a distinctive one, ${ }^{25}$ one might suppose that actors will want the differences on which they pride themselves to stand out and will avoid schemes liable to blur their identity with those they consider quite different from themselves. This is presumably one reason why anarchists and libertarians have often favoured a twodimensional scale in which a Left-Right axis is crossed with another defined by attitudes to authority (cf. the Pournelle and Nolan scales), and why Green partisans sometimes object to a Left-Right spectrum insofar as it obscures what they consider most important and distinctive - their stance towards the environment. It is worth noting however that the preference for a distinctive location in political space may not be universal: in line with recent accounts of the emergence of 'cartel parties', ${ }^{26}$ some actors may pursue the strategy of deliberately blurring their political commitments so as to avoid alienating those who might otherwise vote for them. We shall return to the case of New Labour in a later section.

\section{Legitimising and Subverting}

The Hannan example involves a move ostensibly designed to indicate how partisan groups relate to one another. It can be considered one of a class of efforts to suggest proximity and distance, to accord visibility or withhold it. These are matters of orientation - of indicating to the listener (be it the partisan or the unaligned citizen)

25 Tajfel and Turner 1986.

26 Katz and Mair 2009. 


\section{Left, Right and Beyond}

who 'we' are and how we relate to 'them'. But it will already be clear that such acts of self- and other-positioning are not just about orientation: they are also about asserting the validity of 'our' perspective and casting doubt on that of the opponent. Left and Right are used to signal varying degrees of legitimacy.

When invoked for the purposes of other-positioning, Left and Right are often derogatory categories. They may be used to unmask the opponent, to reveal her true colours and contest a prior act of self-positioning. Consider for example the words of Peter Mandelson, British Minister and senior Labour Party figure, in his speech to the 2009 Party Conference, ${ }^{27}$ in which he seeks to reveal the true nature of the then Conservative opposition and to undermine Conservative efforts to re-position themselves on the political spectrum:

'[...] the Tories seem not to realise that change has to be more than a slogan. The first rule of any marketing strategy is that it must reflect the product it is selling. And what is becoming more evident by the day is that, in their case, it doesn't. The two faces of the Conservative Party are increasingly on show. The one they want to present to the public of a revamped Tory party. And the other that betrays the reality of traditional right-wing Conservatism. [...] Show me what has really changed in the Conservative Party. The truth is that the old Tory right that was rejected in 1997 are quietly feeling at home again with David Cameron.'

[Later]: 'We need to fight back. Of course we do. But to do so successfully it is up to us to explain - with confidence, clarity and conviction - what the choice is. The choice between a Conservative party whose judgements on the credit crunch were wrong, or a party providing leadership in the toughest of times. A choice between a party that lurches to the right the second it sees a chance of doing so, or our party that is resolutely in the progressive centre.'

We shall return to various features of this text, but note for the moment that we have here an account of self-positioning by the Conservatives, as a 'revamped' party at the political centre, being contested as mere show, a kind of false trading which tries but

27 Mandelson, 2009. 
fails to disguise an ugly reality. Precision requires us to say that the self-positioning here is in fact a form of other-positioning, for we encounter it as it is reported by an opponent. Having rejected the reported move, the speaker instead re-positions the party as the latest form of 'traditional right-wing conservatism' and the secret home of the 'old Tory right'. By invoking the political spectrum, the speaker conjures tensions in the opponent's self-positioning, suggesting they seek to occupy two positions at once, with the connotations of disingenuousness and confusion this brings. ${ }^{28}$

The word 'lurch' can be read as underlining the unsubtle, abrupt and uncontrolled nature of this return to basic instincts. It is a word which is commonly paired in English with 'Left' and 'Right' when these terms are pinned to the opponent, and indeed a senior member of the Conservative party had used it just a few months before to accuse the Labour party of 'lurching left - off the centre ground that Tony Blair put them on all those years ago.'29 Again, we see the notion of a reversion to type. The two speakers use identical language, yet try to represent recent British politics in quite asymmetrical ways. Note that, theoretically at least, the one who speaks first has a first-mover advantage, since they can position themselves as they wish and can force a position onto their interlocutor. Of course, even in a smallscale, private conversation, so long as it is of a certain duration, this advantage may be insufficient to determine the outcome of the discursive exchange; in the political case the advantage is yet weaker, since debate is ongoing and one struggles to identify a beginning and end. Still, certain institutional factors may accord a small advantage of this kind: those in government may have opportunities to position their opponents in advantageous ways, for instance as reactive rather than initiatory, critical rather than constructive.

\footnotetext{
${ }^{28}$ This seems to have been a Labour strategy: see the similar language used by James Purnell one year earlier: 'With their warm words and slick positioning, it is hard to convince people of the argument that the Tories have not changed, but the evidence is there. Occasionally the mask slips and we see the dangerous, old- fashioned Tory rightwing instincts hidden underneath.' See http://www.guardian.co.uk/politics/2008/sep/09/labour.conservatives for further discussion of this as an electoral strategy.

${ }^{29}$ George Osborne: Budget 2009 Debate Speech, 23 April 2009.
} 


\section{Left, Right and Beyond}

Mandelson positions Labour as being 'resolutely in the progressive centre'. He thus desists from using 'Left' or 'Right' for self-positioning - to align with the Left for instance would risk acquiring some of the negative associations the term may carry, e.g. of moralism and a lack of realism. Yet by invoking the centre he is still drawing on the idea of a Left-Right spectrum, albeit gravitating to the mid-point on the continuum (see below for further discussion). The idea of a Centre is in a sense an artefact of the spectrum metaphor - and whether ideological positions merge into each other as part of a continuum is less obvious than the metaphor implies. Note the connotations of neutrality and reasonableness which this Centre brings with it, coupled with the implication that positions far from the Centre are of suspect rationality, perhaps also of marginal political relevance. Here we see how selfpositioning and other-positioning interrelate, and how each position carries moral content. As Daalder notes, ${ }^{30}$ a Left-Right spectrum invites the superimposition of a normal-distribution curve at its centre, implying - sometimes quite spuriously - that this is where majority opinion lies and that views located away from the centre are held only by a small minority. Yet Mandelson seems concerned to emphasise that occupying the Centre does not imply indifference to the question of conservatism vs progress, hence the need to qualify the centre (this one at least) as 'progressive'. ${ }^{31}$

One way in which opposing views may be undermined using 'Left' and 'Right' is by playing on some of the specific negative associations these terms have accrued in contemporary political culture - e.g. naivety on the Left or heartlessness on the Right. ${ }^{32}$ And by invoking these connotations, speakers can reinforce them and thereby reinforce their future utility. But the effort to subvert need not necessarily rely on the specific semantic associations of Left and Right: the terms can be used instead to suggest that the opponent's viewpoint is merely one amongst many. To call something a 'right-wing' viewpoint is immediately to suggest that there are other valid viewpoints to be had, that it is but one of many and necessarily

\footnotetext{
30 Daalder 1984, p.95.

31 Likewise, note how Hannan speaks of the 'mainstream Right', a term which explicitly contests the possibility that to be of the Right is to be away from the majority.

32 For some discussion of the etymology of the terms in major European languages, see Sartori 1976, p.298.
} 
susceptible to critique. One might call this 'weak subversion': it does not automatically suggest that the initially proffered view is invalid, but it suggests at least that it must defend itself against other valid perspectives. It places a questionmark beside it. Insofar as Left and Right are commonly assumed to make up a horizontal axis whose component points carry connotations of equal legitimacy, ${ }^{33}$ placing a viewpoint on this axis is to suggest that it carries the same burden of justification as other views.

Left and Right can also be used for what one may call 'strong subversion': here the speaker's intention may be understood as not simply to suggest the target position is one amongst many, but to suggest that it is blinkered and partial. In the Gordon Brown text examined later - 'Why the Right is Wrong' - the word 'Right' is often paired in this sense with 'ideological' (e.g. p.18). To be Right, it is implied, is to take just one side's perspective on things. Speakers may heighten the effectiveness of this by suggesting that Left and Right are not so much consciously, rationally chosen viewpoints as identities, things so deeply ingrained in the opponent that she is unable to shake them off. (Think back to the notion above of parties 'lurching' back to their core selves.) When Left and Right are conjured as identities, the opponent's views are presented as simply an extension of who they are. Just as someone might delegitimise a favourable account of Josip Tito by positioning the speaker as a Yugoslav nationalist, or criticism of Israel by casting the speaker as anti-Semitic, they may subvert a favourable account of the market by positioning the speaker as 'rightwing'. Such a positioning move relies on a kind of genetic fallacy, suggesting a view is invalid because 'she would say that, wouldn't she'. It is little reliant on the particular semantic content of Left and Right in a given time and place, since it is almost always considered the mark of bias or irrationality to advocate something simply because of who you are. Hence the incentive for speakers as above to resist this type of classification by positioning themselves as of 'the Centre'.

An interesting piece of empirical research suggests some party activists may be acutely aware of the dangers of appearing constitutively 'Left' or 'Right'. In a series

${ }^{33}$ Laponce, 1981. 


\section{Left, Right and Beyond}

of discussions with local councillors in Britain, David Weltman notes the consistency with which speakers question the enduring relevance of Left and Right, particularly as descriptions of their own activity, while all the while affirming the sincerity of their political engagement. ${ }^{34}$ It is observed how speakers' autobiographical narratives tend to evoke them as consistently independent of Left and Right - as non-ideological, non-partisan even - and to suggest that Left-Right politics is what others do. Rather than subsuming themselves within a collective political identity, be it Left, Right, or a party label, speakers carefully seek to maintain the autonomy of their selfhood, describing their political work in terms of a contingent overlap between their personal political goals and the instrumental opportunities which the party affords. One may interpret this as an effort to ward off the possibility of being positioned constitutively as 'of the Left' or 'of the Right' and to sidestep the unwelcome delegitimising effects which may accompany this. ${ }^{35}$

\section{Evoking Continuity and Rupture}

Beyond the usages discussed, Left and Right can also be deployed to evoke a historical context for the events of the present. The terms suggest continuity, both in who the protagonists of political conflict are and in the stakes over which they struggle. They can be used to give unified meaning to what otherwise might appear a series of disconnected, local disagreements, and to evoke an enduring constituency - something which ultimately may assist in the mobilisation of supporters. As we have said, this notion of an enduring core meaning to political conflict may be suspect, but it is powerfully suggested by the historical lineage of the categories nonetheless. Indeed, the appearance of continuity may have special appeal in times of flux, when the reality of political conflict is arguably more complex and the stability of party groupings is uncertain. ${ }^{36}$ When parties themselves are prone to appear and disappear in quick succession, and their own names are therefore an

\footnotetext{
34 Weltman 2003; Billig \& Weltman 2001.

${ }^{35}$ Effects heightened in an age when strong ideological commitment is deemed rare and suspect - cf. discussion of the Third Way below.

${ }^{36}$ Cf. Gauchet p.241, pp.259-261.
} 
insufficient basis for suggesting political continuity, or when their political goals are thought to be undergoing change and their connection with the past is therefore in question, the evocation of ideal groupings which transcend the messiness of reality may have appeal. 'The Left' and 'the Right', categories of the highest abstraction, offer this possibility.

It is a possibility which can be drawn upon in day-to-day politics, and we have seen above Peter Mandelson's desire to cast the contemporary British Conservatives, for all their talk of change, as the latest incarnation of a right-wing tradition. It is a possibility which can also be drawn upon when a party chooses its name, an interesting case of which is the German Left Party (Linkspartei). The Left Party was formed in June 2007 out of a merger of the Party of Democratic Socialism (the successor to the ruling party of the DDR, the Socialist Unity Party) - and the Electoral Alternative for Labour and Social Justice (WASG). The first achievement of the name 'Left Party', coined in the years immediately preceding this merger, ${ }^{37}$ is to suggest unity under conditions of fragmentation. The movement out of which the party formed was (and remains) divided in multiple ways: territorially between East and West, ideologically between reformist and pragmatist ex-communists and radical ex-social democrats, and strategically between parliament- and movementoriented partisans. ${ }^{38}$ The abstract terminology of 'Links' facilitates efforts to alleviate these divisions, both due to its simplicity and due to the way it affirms the broad contours of the party's ideological genealogy while affording the party the space neither explicitly to acknowledge or to deny its links with the DDR. ${ }^{39}$

But more than this, the name entails the supra-partisan category 'Left' being appropriated to act as a partisan label. This allows the party to position itself as the authentic inheritor and consolidator of a political tradition, to evoke its place in history, while implicitly raising the possibility that other German parties which

\footnotetext{
37 It was the PDS which first changed its name, in June 2005, to Die Linkspartei.PDS. The move accompanied the invitation to WASG candidates to run on the PDS electoral list for the 2005 federal elections; in an indication of sensitivity to naming issues, these western-German candidates were allowed to omit the PDS reference if they considered it an electoral liability.

${ }^{38}$ Cf. Programmatische Eckpunkte, 2007.

39 Ideological labels such as 'Communist' or 'Socialist' would have made such ambiguity harder to sustain.
} 


\section{Left, Right and Beyond}

position themselves as on the Left (or are conventionally thought to be such) are in some way impostors, that they are discontinuous with that tradition, perhaps even of the Right. To understand this case of 'forced positioning', the political context of the Linkspartei's formation is important..$^{40}$ One needs to recall that Germany's major parties of the Left, the SPD (in particular) and the Greens, had widely been seen as abandoning certain core commitments since, in coalition government under Schroeder in 2003, they had introduced the Agenda 2010 / Hartz laws. Nearly 200,000 members left the SPD in this period, and the party was regarded by many, even if it did not always endorse this, as having completed a break with its left-wing past and a move towards a 'Neue Mitte'. ${ }^{41}$ The Linkspartei, by positioning itself not just as 'of the Left' but as 'the Left' (and the word 'party' often drops out of the name to leave just 'Die Linke'), casts itself as prototypical, as the key landmark on the evacuated political terrain. It is partly a case of partisan profiling as described above. More generally, one needs to recall the wider doubts since the end of the Cold War concerning the continued relevance of left-wing politics, and concerns that, with the absence of major ideas-based oppositions, politics will become emptied of meaning and citizens will have little reason to engage. By drawing so prominently on the term 'Left', the Linkspartei seems to assert that the stakes of political conflict are as serious and meaningful as ever, that politics entails an authentic clash of ideas and not just a trivialised clash of personalities. The conflict is thereby 'dignified'. By styling itself in these terms, the party presents itself as the re-emergence of a longstanding historical force ('eine strategische Neuaufstellung der Linken in Deutschland', as PDS Chairman Lothar Bisky declared when announcing his party's change of name ${ }^{42}$ ), and makes available a political identity for those who might incline to it.

Such observations can be made independently of information about the thoughtprocesses of individual decision-makers: whether all such considerations were the stuff of cognitive reflection in the particular case is probably unknowable, and an

\footnotetext{
40 On forced positioning, Harré and van Langenhove 1992. Attention to the historical context is crucial since there are cases where a party's name must be read very differently: that of the Danish Left Party (Venstre) is today widely regarded as an anachronism (it is generally seen as a party of the Right) and must be traced back to its nineteenth-century origins.

41 Jünke 2007.

42 Bisky, 2005.
} 
understanding of the pragmatic possibilities 'Left' and 'Right' offer is not dependent on knowing it. But consider nonetheless Bisky's words when elaborating on the spirit of the name change, in which many of these thoughts are made explicit:

'Even though the real work on the project for a new Left in Germany begins only after the Bundestag election, nonetheless a signal should be given, in the name of the party standing for election, of our intention to begin something new. A lot of emotions and traditions hang on a party's very name. At stake is the protection and development of identities. At the same time, the chances of such a future project must not be gambled away. [...] With this change of name, the PDS makes clear that, having respect for its history and the protection of its programmatic core, it is ready to widen its identity and thereby become the seed-crystal for a new Left in Germany. With this name, the voters know where they stand. There are no false pretences. I call on the members of the PDS to take this step and in so doing to open up new perspectives for the Left in Germany. One can call this opportunity historic or not, as one prefers. But the opportunity of the moment is this: to create in Germany an example that shows that the Left is not in the process of fracturing itself ever further but on the contrary is coming together and joining as one; to create an example that shows how something which has different roots in East and West, and which until today has represented and addressed two quite different social milieus in the two places, can grow together equally; to establish in Germany a political power to the left of the SPD which can evolve into a permanent presence as the third-strongest political force; to improve the chances for a politics of social justice, of peace and democracy. When I look at the latest manifesto proposals of the SPD and the Greens, I can only say this: Red works [Rot wirkt]. ${ }^{33}$

Set amongst the discussion of new beginnings, notice the emphasis on continuity the notion of a 'new Left' sets the party in a historical tradition, as does the reference to the colour red - and the gesture to the idea of authenticity in the suggestion that

43 Bisky 2005, author's translation. 


\section{Left, Right and Beyond}

the Party presents itself to voters without false pretences. The SPD and Greens are evoked as a foil, and the SPD positioned in limbo with the suggestion that the Leftto-come lies somewhere to its left. Evident too is the concern to evoke unity in the context of division, to transcend a history of splits and the diverse trajectories of East and West, combined with the notion that the Linkspartei may act as the core around which a wider renewed Left coalesces. Through this careful management of the Party's identity, the speaker is able to emphasise the novelty of the moment while nonetheless ensuring that these developments remain recognisable as continuations of the past.

We have seen above how the application of Left and Right may be contested in the specific instance. The appellation 'Left' or 'Right' may be used unreflexively in a first-order act of positioning (of the self or others), or it may be explicitly rejected. Arguably more radical than either move is to contest the very meaningfulness of the vocabulary itself, suggesting the terms are no longer relevant to contemporary politics. Rather than suggesting 'I am neither Left nor Right, though my opponent is' (as in the Mandelson quotation above), here the speaker suggests that the terms are in fact of little applicability to anyone. This has been a fairly common trope in recent years amongst those endorsing a 'third way', although rejections of Left and Right are often qualified. At first sight this would seem to be not so much a usage of Left / Right as a disavowal of such usage. Yet to reject something explicitly - as opposed simply to overlooking it - is of course at the same time to acknowledge it, and moreover to seek to capitalise on its meaning.

Explicit denigrations of Left and Right may be made exactly to undermine the continuity of political time which the categories suggest, and instead to herald a rupture. British New Labour discourse in the mid-1990s was well stocked with notions of going 'beyond Left and Right'. ${ }^{44}$ This can be understood partly in terms of the points already noted: the desire to avoid having oneself tagged as ideological and partial rather than free-thinking, and to avoid association with thinking apparently discredited after the Cold War. One can present oneself as fresh and

${ }^{4}$ Cf. Blair 1998, Giddens 1994. 
independent. Yet such goals would have been adequately achievable simply by repositioning the party at the centre of a still-affirmed Left-Right continuum - in the spirit perhaps of Macmillan's 'middle way', or the German SPD's Neue Mitte. To suggest instead that the very idea of the continuum is emblematic of 'old-style politics' is to go a step further: it evokes a more deep-seated Zeitgeist in which the country as a whole and its politics are cast as 'new' or 'young' and the links with the past are severed..$^{45}$ One might say that Blair's Labour declared not just that it itself and its subjective preferences had changed but that political life as a whole had changed: everything New Labour is then in a sense merely symptomatic of a new Britain. (It is a move which neatly enables later claims that everything which is of 'new Britain' is in fact of New Labour.) The negative usage of Left and Right - a usage nonetheless - thereby allows the assertion of discontinuity and new beginnings, a kind of 'year zero' in the life of the country and not just the party, thereby evoking a more general atmosphere of possibility, of a new politics outside the conventional 'mainstream', and wrong-footing those opponents who would seek to reposition the party with appeal to the Left-Right spectrum. ${ }^{46}$

\section{Substitutions}

To renounce categories explicitly, and to do so repeatedly, is in a sense not to renounce them at all, since in doing so they continue to act as reference-points. For as long as speakers feel the need to assert the redundancy of Left and Right, the

\footnotetext{
${ }^{45}$ It is an effort to transcend the scale - to evoke in Bobbio's terms an 'inclusive' rather than an 'included' middle. Note though that several Third Way texts are ambiguous in their attitude to Left and Right: see for instance the Blair / Schroeder joint document in 1998, which begins by claiming the terms have lost their relevance before going on to propose 'a new supply-side agenda for the Left'. (Such formulations seem designed to disrupt the conventional associations of 'Left', in this case with demand-side economics.) On New Labour's inconsistency regarding whether the Third Way is 'beyond Left and Right' or just an updated Centre-Left, see Driver \& Martell 2000.

46 Note that narratives concerning the demise of Left and Right can trade on the ambiguity regarding whether Left and Right is a space defined by parties or by ideas (or currently-existing elite views vs the range of views in society, today and in the past). Those suggesting the terms are no longer meaningful may try to infer from a lack of contestation on the current political scene that such contestation is no longer conceivable - a view which implicates the world of ideas.
} 


\section{Left, Right and Beyond}

continuity of political time has not been and cannot be fully ruptured. Left and Right are 'sticky' categories in this sense: like glue on the fingers, efforts to remove them can end up dispersing them. But there is of course a different scenario, in which what one sees is not so much the loud renunciation of the terms as their quiet avoidance. The possibility is conceivable given, as we have seen, the terms come not only with utility but with pitfalls, particularly when applied to the self. Insofar as the symbolic capital of political mapping is too precious for political actors to abandon altogether, there is instead the prospect that 'Left' and 'Right' come to be substituted with alternative terms promising the benefits without the drawbacks.

Consider the following. Shortly before the May 2010 British General Election, Prime Minister and Labour leader Gordon Brown released under his name a pamphlet headed 'Why the Right is Wrong'. ${ }^{47}$ This was a complex and sizeable text, though presumably intended to have electoral influence. As the title suggests, the term 'Right' features prominently: 63 times, not including the running title which places it on each second page. Indeed, the author goes out of his way to apply it, not just to domestic debates but to international affairs, where Left-Right traditions can be especially amorphous. Notwithstanding the Party's interest in narratives of 'beyond Left and Right', such enthusiasm is understandable given the term's usefulness in evoking a single, intransigent opponent to be resisted. Yet one striking aspect of the text is the rarity of the term 'Left': it features just four times. That Left-Right disagreements are meaningful is affirmed: 'Left and Right, Labour and Tory, progressive and conservative - these labels represent real and important differences in how we understand the world and the society in which we live ....'48 Left-Right divergence on the value of equality is emphasised. Yet for the most part the authorial perspective is not presented as a Left one. Instead, it is presented as a 'progressive' one. The word is used 54 times in the text (plus in the sub-title) in a wide variety of formulations: 'progressive values / ideas / thinking / thought / politics / tradition / philosophy and creed', as well as reference to us 'as progressives' and the present as a 'progressive moment'. Thus while the Left-Right vocabulary is

47 Brown 2010.

48 Brown 2010, p.5. 
by no means absent in the text, one of its terms has been substituted, with the key opposition cast as Right vs progressive.

Brown's text is by no means the only place where 'progressive' has recently made its appearance in this form. It features in Mandelson's words above, in the work of Labour-related thinkers, ${ }^{49}$ and it became widely visible during the election campaign itself. $^{50}$ As noted earlier, political mapping can acquire added urgency under conditions of complexity and flux, when the names of the major parties become inadequate as guides to the political scene and when categories of higher generality are sought. Such were the conditions in this election when it became clear no party was likely to win an outright majority of parliamentary seats and that some form of coalition government might be necessary. The emergence of the Liberal Democrats during campaign polling as plausible determinants of the post-electoral configuration encouraged efforts both to find ways of mapping that configuration and of influencing it by evoking the sympathies needed for so-called 'tactical voting'. Through repeated mention of a possible 'progressive alliance' or 'progressive coalition', generally understood as between Labour and the Liberal Democrats, one could hope to profile these parties as closely akin, and thereby convince their supporters to vote for each others' representatives in constituencies where this offered the best chance of defeating the Conservatives. Out of an increasingly unstable situation a dualistic order could be asserted anew.

Like the term 'Left', 'progressive' has immediate appeal as a category of political abstraction in that it cannot be reduced to any one political party or ideological tradition. No-one has written the definitive progressive manifesto; it can only be used as a cluster-term. As a term of substitution for the 'Left' (which it is certainly not always), it offers clear possibilities for partisan profiling. In Brown's text it functions to position the self as forward-looking and in tune with a presumed appetite in the general public for a 'new politics', and to mark out an opponent

\footnotetext{
${ }^{49}$ Giddens 2003.

${ }^{50}$ Reporting Brown's use of 'progressive alliance', see Andrew Grice, The Independent, 21 April 2010: www.independent.co.uk/news/uk/politics/brown-trains-his-sights-on-a-new-politicsndash-with-the-help-of-the-lib-dems-1949585.html.
} 


\section{Left, Right and Beyond}

which by definition cannot then claim these qualities. One of its plausible paired opposites - 'conservative' - neatly isolates the major political opponent, yet the term is not so unambiguously adversarial as to exclude a more consensual, bipartisan reading. At the same time it hints at cross-temporal continuity. Just as the Linkspartei's use of 'Left' lifts eyes from a particular time and place to the ongoing relevance of long-standing traditions, 'progressive' points to deep-seated oppositions of principle rather than the ephemeral and personality-based oppositions some might infer from conflict in its party guise (Labour and Conservative). In line with the text's philosophical references, adversarialism is given seriousness and 'substance'. Moreover, the term avoids some of the pitfalls of 'Left' for self-positioning: it avoids the suggestion of marginality and deviance, allowing the 'progressive' to claim he / she is of the Centre (cf. Mandelson) and the majority. Also, while both terms can function as both adjectives and nouns, 'progressive' as a noun is more easily pluralised (as it often is in Brown's pamphlet). Whereas 'the Left', as a capitalised, collective singular, suggests a monolithic bloc, 'progressives' as a plural form suggests an aggregate of people who retain their individuality while happening to share certain values. Pluralism in form hints at pluralism in ethos, evoking individuals who are independent-minded and diverse.

If 'progressive' initially seems more than adequate as a substitute for 'Left', this view needs qualifying. ${ }^{51}$ First, its pairing with 'Right' in the text cited is indicative of its limitations. 'Progressive' lacks an accepted and credibly endorsed counter-concept. That few political actors in the modern world would resist the description 'progressive' is both its strength and weakness: it enables the speaker to describe themselves in a way that maximises their appeal (and Brown reiterates that his values are those of the 'British people' as a whole), but at the expense of being able to conjure a plausible opponent. Readers will be familiar with the fact the Conservative leader David Cameron soon positioned his own party's post-electoral coalition with

${ }^{51}$ As generally, adequacy is understood here in terms of usefulness for specific actors rather than wider political goods, the latter being beyond the scope of this paper. 
the Liberal Democrats as a 'progressive partnership'. ${ }^{52}$ Once the appeal of a term becomes commonsensical, that appeal may dissipate. Second, the term 'progressive' does not permit gradation. Whereas 'centre-Left' is ostensibly meaningful, 'semiprogressive' or even 'moderately progressive' seems to jar. One struggles to identify the distinct strands of a 'progressive coalition' using the same terminology, whereas those of a 'centre-Left' coalition can themselves be submitted to Left-Right analysis. ${ }^{53}$ Third, the prestige of 'Left-Right' is underpinned by its transnational diffusion. Alternative umbrella terms face the challenge that, being less widely established, they are liable to seem parochial. This in itself may diminish their credibility. And lastly, to the extent Left and Right have certain problematic connotations when applied to the self, they retain - as Brown's text indicates - an inverse appeal for the positioning of others.

Concepts evolve, and an assessment of their applicatory potential needs ongoing revision. Yet in the near future the substitution of the Left-Right idiom by alternative vocabularies seems likely to be no more than partial. 'Left' and 'Right' can be expected to persist, perhaps even to retain their status as the resources for mapping par excellence. Practices of substitution remain significant however, for they enable what is impossible using just the one vocabulary. What they permit a speaker is the ability to seek refuge from the outrageous simplicity and contestability of any one particular mapping scheme. Left, Right and their alternatives are highly imperfect analytical tools, and speakers will occasionally need the option of taking distance from the categories or casting them in an ironic light. They will need the capacity to suggest that, however problematic we know 'Left', 'Right' and their alternatives to be, the underlying configuration they refer to is real. Synonyms, and terms used as functional equivalents, provide just this possibility. When Brown sets a series of oppositions side by side - 'Left and Right, Labour and Tory, progressive and conservative' - he gives an apparent credibility to the dualistic political order he wishes to evoke, and avoids loading any one of these oppositions with the entire

52 Cf. Cameron's Downing St. garden press conference with Clegg, 13 th May 2010: www.independent.co.uk/news/uk/politics/cameron-and-clegg-hail-a-new-political-era-ontheir-first-day-in-power-1972259.html

53 For a similar point in relation to colour imagery, see Gauchet 1994. 


\section{Left, Right and Beyond}

burden of descriptive plausibility. Each compensates in some measure for the inadequacy of every other. Having secured the reality of the object world, he is then free to pursue the combination best suited to the purposes of the text.

\section{Conclusion}

We have seen that the categories of Left and Right have a life beyond their existence as tools for analysis by the detached political observer. Political actors put them to use to position themselves and others, achieving a number of effects thereby, of which three salient ones have been explored. The terms thus act as a versatile political resource, one whose prestige is no doubt consolidated by the fact that they nonetheless hint at being more than merely partisan, at being the stuff of objectivity and cold analysis. The examples we have examined show Left and Right being used by political actors commonly associated with both, and in the varied contexts of Germany's entrenched system of proportional representation and Britain's Westminster model. The latter in particular is something of a critical case, given that Left-Right talk is more conventionally associated with complex political scenes involving many political actors, and given the political hegemony of a party making at least some claims to have gone 'beyond Left and Right'.

These reflections suggest a number of things. They suggest first that a full understanding of these political categories must go beyond the effort to specify their semantic content, whether understood as a universal dualism or a time- and spacebound construct. Without rejecting the validity and value of such discussions, one should not overlook the ways Left and Right are employed for the purposes of positioning. Studying the categories in this way suggests, second, that there are reasons to expect them to remain in currency for some time yet. For as long as political actors find their usage productive, their full disappearance seems unlikely. Even the tactic of disavowing them has proved partial and temporary in some salient cases: Labour thinker Anthony Giddens, despite talk of 'breaking out' of past ways of thinking and of going 'beyond Left and Right', long continued to speak of the 
Third Way as a reinvention of the Centre-Left, and more recently has suggested that the critical stance towards the Left-Right vocabulary was but a short-term strategy for emphasising a break with some of the traditional commitments of socialist thinking. ${ }^{54}$ The pragmatic appeal of the vocabulary remains evident. There are no doubt other terms which can be used for political mapping - we have looked at the word 'progressive' - and one cannot exclude that some will show themselves more useful than Left-Right. But such substitutions seem unlikely to be wholesale, for the very multiplicity of terms can itself be useful. And here potentially is a point of some democratic significance. If, as some have argued, the imagery of Left and Right is one there are reasons to want to see preserved, it is important to consider what motives political activists, as those in a privileged position to maintain the usage of the vocabulary, might have for evoking it. The functional benefits which accrue at the systemic level may well be an insufficient motivation, and local purposes may need to be present: hence the importance of examining what partisan objectives the usage of the vocabulary may serve and which may therefore keep the terms in circulation.

One may wonder of course whether they will persist in a form conducive to their resonance amongst a wider public. Our discussion has dwelt on usages which are at least to some degree rhetorical and opportunistic in character, and which conjure a political scene heavily influenced by tactical calculation. If it is in this guise that Left and Right find public expression, rather than as devices for representing differences of principle, the possibility that the categories become poisoned through negative association would seem real. Should they come to be associated mainly with acts of partisan positioning, with efforts to tar political opponents rather than to evoke meaningful differences, what uses would they then hold for non-partisans, i.e. for the majority of citizens?

The retreat of the Left-Right vocabulary into a small speech community of political elites is evidently one possible scenario. Of these elites, perhaps only a subset of political 'mavericks' will be inclined to promote these terms consistently and

${ }^{54}$ Cf. Noel and Therien pp.188-9, Giddens 2003, Intro. 


\section{Left, Right and Beyond}

positively, as anchor-terms for the political visions they wish to be associated with. It is noticeable that the most explicit act of self-positioning we have considered - that of the Linkspartei - is one made from the political margins, by a party with little invested in the status quo. By contrast, in Mandelson's text, and to a lesser extent in Brown's, Left and Right signify either mere locations on an external landscape, or protagonists but protagonists to be opposed. By political actors wishing to appear moderate and pragmatic, a principled invocation of the terms may be rare.

It is important to note however that even tactical usages of Left and Right are not necessarily incompatible with the idea that Left and Right signal deeper commitments. Some that we have considered, such as the effort to evoke the seriousness of political clashes by setting them in a larger cross-temporal context, seem predicated exactly on this idea. Likewise Hannan's move to reconfigure the relations between Conservatives, Labour and the BNP, which draws its urgency from the notion that Left and Right are carriers of meaning - meaning which may be dangerous if it is not nailed with precision. The continued existence of some level of stabilised semantic content going beyond the local application of the terms would seem to be a prerequisite for these categories being useful political resources to partisans in such ways. And even when they are invoked for the most local of reasons, like concepts in general they bring with them more meaning than the single speaker intends. Left and Right remain categories of abstraction which invite the listener to look beyond the merely local, beyond the here-and-now, to a larger temporal and spatial context. To this extent the relationship between the tactical usage of the terms and their more principled democratic role may be more harmonious than initially appears. 


\section{References}

Anderson, Perry (1998) 'A Sense of the Left', New Left Review 231, pp.73-81.

Bisky, Lothar (2005), PDS Chairman's Press Conference Statement following sitting of the Party

Executive Committee, 22 June, www.netzwerk-

venezuela.de/index.php?option=com content\&task=view\&id=87\&Itemid=14

Blair, Tony (1998), The Third Way: New Politics for the New Century (London: Fabian Society).

--- and Gerhard Schroeder (1999), Europe: The Third Way / Die Neue Mitte (London: Labour

Party).

Bobbio, Norberto (1996). Left and Right: The Significance of a Political Distinction (Cambridge:

Polity).

Bourdieu, Pierre (1991), Language and Symbolic Power (Cambridge: Polity).

Brown, Gordon (2010), Why the Right is Wrong: the progressive case for Britain's future (London:

Fabian Society), www.fabians.org.uk/images/Why the Right is Wrong WEB.pdf.

Daalder Hans (1984), 'In Search of the Center of European Party Systems', American Political

Science Review, 78 (1), pp. 92-109.

Driver, Stephen and Luke Martell (2000), 'Left, Right and the Third Way', Policy and Politics 28

(2).

Dyrberg, Torben B. (2005), 'The Democratic Ideology of Right-Left and Public Reason in Relation to Rawls's Political Liberalism', Critical Review of International Social and Political Philosophy 8(2), pp.161-176.

Eatwell, Roger (1989) 'The Rise of "Left-Right” Terminology: The Confusions of Social Science', in The Nature of the Right, ed. Eatwell and N. O'Sullivan (London: Pinter), pp.32-46.

Fuchs, Dieter, and Hans-Dieter Klingemann (1990), 'The left-right schema', in Continuities in Political Action: A Longitudinal Study of Political Orientations in Three Western

Democracies, ed. M .Jennings et al. (Berlin: de Gruyter), pp.203-34.

Gauchet, Marcel (1994) 'Left and Right', in Pierre Nora (ed.) Realms of memory: rethinking the

French past, Vol.3, Symbols (New York: Columbia UP).

Giddens, Anthony (1994), Beyond Left and Right (Cambridge: Polity).

--- (ed.) 2003, The Progressive Manifesto (Cambridge: Polity).

Harré, Rom and Luk Van Langenhove (1992), 'Varieties of Positioning', Journal for the Theory of Social Behaviour, 20, pp.393-407.

--- (1999) (eds.) Positioning Theory: Moral Contexts of Intentional Action (Oxford: Blackwell).

Harré, Rom, and F. Moghaddam (eds.) (2003). The Self and Others: Positioning individuals and groups in personal, political, and cultural contexts (Westport, CT: Praeger).

--- and Lee, N. (eds.) (2008), Global Conflict Resolution through Positioning Analysis (New York:

Springer).

Jünke, Christoph (2007) 'A New Formation with Potential Pitfalls: The New German Linkspartei', Debatte: Journal of Contemporary Central and Eastern Europe, 15 (3), pp.307-19. 


\section{Left, Right and Beyond}

Kymlicka, Will (2002), Contemporary Political Philosophy: An Introduction (Oxford: OUP).

Linkspartei (Deutschland), (2007), Programmatische Eckpunkte - Programmatisches Gründungsdokument der Partei DIE LINKE, Beschluss der Parteitage von WASG und Linkspartei.PDS am 24. und 25. März (Dortmund).

Laponce, Jean A. (1981), Left and Right: The Topography of Political Perceptions (Toronto: U. of Toronto Press).

Lukes, Steven (2003), 'Epilogue: The Grand Dichotomy of the Twentieth Century' in Ball and Bellamy (eds.), The Cambridge History of Twentieth Century Political Thought (Cambridge: CUP).

Mandelson, Peter (2009), 'Speech to the 2009 Labour Party Annual Conference' www.labour.org.uk/peter-mandelson-speech-conference

Mair, Peter (2007), 'Left-Right Orientations', in R. Dalton and H.-D. Klingemann (eds.) The Oxford Handbook of Political Behaviour (Oxford: OUP), pp.206-222.

Michael D. McDonald, Silvia M. Mendes and Myunghee Kim (2007), 'Cross-Temporal and CrossNational Comparisons of Party Left-Right Positions', Electoral Studies, 26 (1) pp.62-75.

Moghaddam, F.M., Harré, R., \& Lee, N. (Eds.). (2008). Global conflict resolution through positioning analysis (New York: Springer).

Mouffe, Chantal (2005), On the Political (London: Routledge).

Noël, Alain and Jean-Philippe Thérien (2008), Left and Right in Global Politics (Cambridge: CUP). Sartori, Giovanni (1976), Parties and Party Systems (Cambridge: CUP).

Tajfel, Henri and John Turner (1986), 'The Social Identity Theory of Inter-Group Behavior', in Stephen Worchel and William G. Austin (eds.), Psychology of Intergroup Relations (Chicago: Nelson-Hall).

Weltman, David (2003), "The Pragmatics of Peremptory Assertion: an ideological analysis of the use of the word 'just' in local politicians' denials of politics', Discourse and Society 14 (3).

Weltman, David and Michael Billig (2001), 'The Political Psychology of Contemporary AntiPolitics: A Discursive Approach to the End-of-Ideology Era', Political Psychology, 22 (2). 


\section{Recent LEQS papers}

Monastiriotis, Vassilis \& Zartaloudis, Sotirios. 'Beyond the crisis: EMU and labour market reform pressures in good and bad times.' LEQS Paper No. 23, June 2010

Lütz, Susanne \& Kranke, Matthias. 'The European Rescue of the Washington Consensus? EU and IMF Lending to Central and Eastern European Countries.' LEQS Paper No. 22, May 2010

Hartlapp, Miriam; Metz, Julia \& Rauh, Christian. 'The agenda set by the EU Commission: the result of balanced or biased aggregation of positions?' LEQS Paper No. 21, April 2010

Costa-i-Font, Joan. 'Unveiling Vertical State Downscaling: Identity and/or the Economy?' LEQS Paper No. 20, March 2010

Delanty, Gerard. 'The European Heritage from a Critical Cosmopolitan Perspective. LEQS Paper No. 19, February 2010

Outhwaite, William. 'Europe at 21: Transitions and Transformations since 1989'. LEQS Paper No. 18, January 2010

Lavdas, Kostas A..'Normative Evolution in Europe: Small States and Republican Peace'. LEQS Paper No. 17, January 2010

Schelkle, Waltraud. 'Good governance in crisis or a good crisis for governance? A comparison of the EU and the US'. LEQS Paper No. 16, December 2009

Keating, Michael. 'Second Round Reform. Devolution and constitutional reform in the United Kingdom, Spain and Italy'. LEQS Paper No. 15, December 2009

Hyman, Richard. 'Trade Unions and 'Europe': Are the Members out of Step?'. LEQS Paper No. 14, November 2009

Dani, Marco. 'Economic and social conflicts, integration and constitutionalism in contemporary Europe'. LEQS Paper No. 13, November 2009

Rodríguez-Pose, Andrés \& Krøijer, Anne. 'Fiscal Decentralization and Economic Growth in Central and Eastern Europe'. LEQS Paper No. 12, October 2009

Cheshire, Paul C. \& Magrini, Stefano. 'Urban Growth Drivers and Spatial Inequalities: Europe - a Case with Geographically Sticky People. LEQS Paper No. 11, October 2009

McCrea, Ronan. 'The Recognition of Religion within the Constitutional and Political Order of the European Union'. LEQS Paper No. 10, September 2009

Bertola, Guiseppe \& Mola, Lorenza. 'Services Provision and Temporary Mobility: Freedoms and Regulation in the EU' LEQS Paper No. 9, September 2009

Walker, Neil. 'Multilevel Constitutionalism: Looking Beyond the German Debate'. LEQS Paper No. 8, June 2009

Frankel, Jeffrey. 'The Estimated Trade Effects of the Euro: Why Are They Below Those From Historical Monetary Unions Among Smaller Countries?'. LEQS Paper No. 7, June 2009

Colomer, Josep M.. 'On Building the American and the European Empires'. LEQS Paper No. 6, June 2009 


\section{LEQS}

European Institute

London School of Economics

Houghton Street

WC2A 2AE London

Email: euroinst.LEQS@lse.ac.uk

http://www2.lse.ac.uk/europeanInstitute/LEQS/Home.aspx 